\title{
Problem Venezuele u spoljnoj politici Sjedinjenih Država
}

\author{
VLADIMIR TRAPARA \\ Institut za međunarodnu politiku i privredu, Beograd
}

\begin{abstract}
Sažetak
Autor se bavi odnosima Sjedinjenih Država i Venezuele zaključno sa aktuelnom predsedničkom krizom ne bi li odgovorio na pitanje kako i zašto je Venezuela postala problem za spoljnu politiku SAD koji zahteva pojačanu pažnju i radikalne mere. Analiza ovih odnosa u toku 20. veka pokazuje da su oni zasnovani na naftnoj međuzavisnosti dveju država. Kada je krajem veka višedecenijsko loše upravljanje naftnim bogatstvom u Venezueli izazvalo društvenu i ekonomsku krizu koja je dovela na vlast Huga Cháveza, spremnog da koristi prihode od nafte protiv interesa regionalne hegemonije SAD, ove su Venezuelu označile kao problem. Američki establišment je prema tom problemu nastupio oportunistički - naftna međuzavisnost je sprečavala da sukob eskalira sve dok aktuelna ekonomsko-politička kriza u Venezueli nakon Chávezove smrti nije dala Washingtonu priliku za konačni obračun sa režimom, po cenu privremenog prekida u trgovini naftom. Godinu i po dana od izbijanja predsednička kriza u Venezueli još nije razrešena, jer se čavistički režim održao, a SAD odustale od vojne intervencije, pa autor nastoji da ukaže na perspektive problema i mogućnosti njegovog prevazilaženja nakon što tekuća pandemija korona virusa bude obuzdana.
\end{abstract}

Ključne riječi: Venezuela, Sjedinjene Države, spoljna politika, nafta, čavizam

\section{Uvod}

Mesec dana po stupanju na dužnost, predsednik Sjedinjenih Država Donald Trump susreo se sa Lilian Tintori, suprugom venezuelanskog opozicionara i političkog zatvorenika Leopolda Lópeza, koja mu je "objasnila" aktuelnu krizu u Venezueli. Nakon sastanka, Trump je tvitovao zahtev da se López hitno pusti iz zatvora, a u roku od nekoliko meseci Venezuela će se (uz Severnu Koreju i Iran) naći na vrhu liste američkih spoljnopolitičkih prioriteta (Camilleri, 2018: 189-190). Washington uskoro pooštrava sankcije protiv Venezuele, a u avgustu mesecu usledio je i prvi 
Trumpov nagoveštaj da u razrešavanju venezuelanske krize SAD razmatraju i vojnu opciju - pretnja koju će u nastavku krize mnogo puta ponoviti i sam američki predsednik i njegovi najbliži saradnici. SAD - a sa njima i nekoliko desetina država sveta - nisu priznale predsedničke izbore u Venezueli u maju 2018, na kojima pobeđuje aktuelni predsednik Nicolás Maduro, niti će ga priznati za predsednika kada u januaru 2019. bude bio inaugurisan. Umesto toga, Washington je podržao do tada malo poznatog opozicionog lidera koji je došao na čelo Nacionalne skupštine, Juana Guaidóa, priznavši ga za predsednika Venezuele nakon što se ovaj u januaru 2019. proglasio predsednikom pozivajući se na venezuelanski ustav. Usledila je venezuelanska predsednička kriza i vrhunac "klinča" Sjedinjenih Država i ove latinoameričke zemlje, koji do proglašenja pandemije koronavurisa u martu 2020. za koju tek možemo da pretpostavljamo kakav će uticaj imati i na Venezuelu, i na SAD, i na ukupne međunarodne odnose - nije raspetljan. Možda je zato sada pravi trenutak da pokušamo da odgovorimo na pitanje - kako i zašto je Venezuela postala problem za spoljnu politiku Sjedinjenih Država, koji zahteva tako veliku pažnju i tako oštre mere?

Ovaj problem nije počeo sa Trumpom niti sa aktuelnom političkom i ekonomskom krizom u Venezueli. Već je i Trumpov prethodnik Barack Obama, pravdajući sankcije koje je Venezueli uveo 2015, označio ovu zemlju kao "neuobičajenu i izvanrednu pretnju nacionalnoj bezbednosti i spoljnoj politici Sjedinjenih Država" (Kovalik, 2019: 154). SAD vide Venezuelu kao pretnju praktično otkako je za njenog predsednika 1998. godine izabran socijalista Hugo Chávez. Međutim, pogrešno bi bilo uprostiti odgovor na pitanje koje smo postavili tako što bismo isključivi uzrok problema videli u ideološkoj netrpeljivosti washingtonskog establišmenta prema venezuelanskoj varijanti socijalizma, "čavizmu". To i dalje ne bi objasnilo varijacije u oštrini problema - kako su SAD i Venezuela u toku Chávezove vladavine uspevale da drže sukob pod kontrolom, i čak nagovestile otopljavanje odnosa u ranoj fazi Obaminog mandata, a zatim naglo skliznule ka eskalaciji. Niti je ideologija dovoljna da rastumači dubinu trenutne krize u Venezueli, ako se ima u vidu da je sličnih kriza bilo i pre čavizma, te da se on i rodio kao odgovor na jednu od njih.

Traganje za odgovorom na naše istraživačko pitanje, dakle, zahteva da se ode nešto dublje $u$ istoriju ne bi li se razumela geneza specifičnosti venezuelanskog društva, ekonomskog i političkog sistema, spoljne politike te odnosa Venezuele sa Sjedinjenim Državama. ${ }^{1}$ Ovo će biti tema poglavlja koje sledi nakon kratkog teorijskog, u kome ćemo se osvrnuti na oportunističku prirodu hegemonije SAD u La-

1 Primarna korišćena metoda je analiza sadržaja relevantne literature koja se bavi pomenutim pitanjima. U izboru literature vodili smo računa o ravnoteži između naslova koji kritikuju aktuelni režim u Venezueli i onih koji su mu naklonjeni kako bismo izbegli bilo kakvu pristrasnost u zaključcima. 
tinskoj Americi, inače bitnu za razumevanje zaokreta u politici Washingtona prema Venezueli u poslednjih nekoliko godina. Taj zaokret biće tema preostalih poglavlja - u prvom od njih analiziramo uspon čavizma i dinamiku venezuelansko-američkih odnosa koju je on doneo sa sobom, njihovim smeštanjem u pomenuti istorijski kontekst (upotrebom istorijsko-komparativne metode), da bismo $\mathrm{u}$ drugom $\mathrm{u}$ isti kontekst smestili i analizirali i aktuelnu krizu unutar Venezuele i u njenim odnosima sa SAD - od Chávezove smrti 2013, u užem smislu od 2017, a u najužem od izbijanja predsedničke krize 2019. naovamo. Očekivani rezultat, koji iznosimo u zaključku, je puno rasvetljavanje problema Venezuele u spoljnoj politici SAD, zajedno s utvrđivanjem njegovih perspektiva i onoga što bi se moglo preduzeti - i s američke i s venezuelanske strane - da bi se on (nakon stišavanja pomenute pandemije kao trenutno primarnog problema) prevazišao.

\section{Regionalna hegemonija i oportunizam}

Sjedinjene Države su hegemon na zapadnoj hemisferi. Još od Monroeove doktrine 20-ih godina 19. veka, Washington posmatra ostatak američkog kontinenta - dakle i Latinsku Ameriku - kao svoje "dvorište", u kome širokim asortimanom spoljnopolitičkih sredstava obezbeđuje "poslušnost" i kažnjava "neposlušnost" lokalnih aktera i, što je takođe vrlo značajno, suzbija uticaj sila sa suprotne Zemljine hemisfere. U američkom spoljnopolitičkom establišmentu i akademskoj zajednici koja mu daje logističku podršku vlada gotovo nepodeljeno mišljenje da je hegemonija na zapadnoj hemisferi nacionalni interes SAD. Čak ni oštri kritičari američkog hegemonizma na globalnom planu ne osporavaju isti u Latinskoj Americi. Još je Hans Morgenthau, pozivajući se na filozofiju federalista, kao tri "osnovna i nepromenljiva" interesa SAD definisao: obezbeđenje dominantnog položaja na zapadnoj hemisferi; ravnotežu snaga u Evropi; ravnotežu snaga u Aziji (Morgenthau, 1952: 4-6). John Mearsheimer se zalaže za odustajanje Washingtona od politike globalne hegemonije u korist politike "ofšor uravnoteživanja" (off-shore balancing), koja bi podrazumevala kombinaciju održavanja hegemonije u Americi sa sprečavanjem drugih sila da ostvare regionalnu hegemoniju u Evropi, Persijskom zalivu i Istočnoj Aziji (Mearsheimer, 2011: 18). Barry Posen aktuelnoj “velikoj strategiji” liberalne hegemonije koju sprovode SAD suprotstavlja strategiju "uzdržavanja" (restraint), koja takođe dovodi u pitanje samo globalnu, ne i regionalnu hegemoniju (Posen, 2014: 69-87).

Nijedan od ovih autora ne kritikuje američki globalni hegemonizam zato što je on ideološki, moralno ili filozofski upitan, već prosto zato što smatraju da je globalna hegemonija - neizvodljiva. Prema Mearsheimeru, "zaustavljajuća moć vode" onemogućava uspostavljanje kontrole nad udaljenim prekookeanskim područjima (Mearsheimer, 2001: 41-42). Posen čitavo poglavlje u svojoj knjizi posvećuje raz- 
matranju direktnih i indirektnih troškova liberalne hegemonije (Posen, 2014: 2468). Suprotno globalnoj, politika hegemonije na američkom kontinentu smatra se izvodljivom i, samim tim - opravdanom. No, to što je izvodljiva generalno ne znači da Washington nastoji i uspeva da u svako doba u punoj meri kontroliše svaki kutak zapadne hemisfere. Kada se to - bilo zbog snage lokalnog otpora, bilo zbog uticaja vanhemisfernih sila ili nekog trećeg razloga - pokaže neisplativim, SAD prihvataju da privremeno tolerišu "neposlušnost" nekog od regionalnih aktera, ne posežući za krajnjim sredstvima obračuna s njim, kako ne bi iscrpljivale resurse potrebne za očuvanje šire regionalne hegemonije - kao što to čine sa Kubom već više od pola veka. Takođe, SAD pokazuju fleksibilnost u pogledu sredstava koja im se čine efikasnijim za održavanje "poslušnosti" - primer za to je nagla promena politike prema Latinskoj Americi u drugoj polovini 80-ih, od podrške desničarskim diktatorima ka rušenju istih i promovisanju umerenih demokratskih pokreta. I doktrinu i praksu američke hegemonije na zapadnoj hemisferi karakteriše oportunizam - asertivni pristup u nametanju kontrole kada se oceni da su prilike za to povoljne, a uzdržavanje ili čak povlačenje u odnosu na neke aktere kada one to nisu. Dinamika američke politike prema Venezueli savršeno se uklapa u ovu matricu. U nastavku rada dokazujemo tezu da je upravo američki oportunizam, izazvan naftnom međuzavisnošću sa Venezuelom, obuzdao Washington od isuviše radikalnih mera prema čavističkom režimu dok je ovaj bio stabilan; no, kada se režim suočio sa dubokom krizom, isti oportunizam vodiće SAD ka eskalaciji sukoba do ivice vojne intervencije, i to čak po cenu privremenog kidanja naftnih veza.

\section{Uspon i pad naftnog savezništva}

Problem koji Venezuela ima sama sa sobom, a iz koga će delom proizaći i problem koji Washington ima s njom, može se predstaviti prostom jednačinom: nafta + Latinska Amerika $=$ problem. Venezuela raspolaže najvećim potvrđenim rezervama nafte u svetu - oko 300 milijardi barela (Gallegos, 2016: 150). Pre najnovijeg pada, bila je najveći latinoamerički proizvođač i izvoznik nafte, i jedina je članica (i to osnivač) OPEC na zapadnoj hemisferi. Otkriće najvećih naftnih nalazišta i početak masovnije eksploatacije nafte 20 -ih godina prošlog veka (u vreme diktatora Juana Vicentea Gómeza) promenili su istoriju Venezuele, ali i njen odnos sa moćnijim susedom sa severa - nafta od tog trenutka postaje ne samo glavna poluga venezuelanske ekonomije, već i središnja komponenta njene kulture i identiteta, kao i srž odnosa Venezuele i SAD (Salas, 2015: 1, 4-5, 61-62, 67-68; Kovalik, 2019: 33-34). Ključnu ulogu u eksploataciji "crnog zlata" u početku su imale američke kompanije, ali će Venezuelanci postepeno shvatiti da mogu i sami da upravljaju svojom naftom, u sopstvenu korist. U periodu od naftnog zakona 1943, kojim je profit podeljen 50:50 između države i stranih kompanija, pa do nacionalizacije naftne industrije i 
stvaranja državne kompanije PDVSA (Petróleos de Venezuela, S.A.) 1976, i elita i stanovništvo Venezuele navići će se na trošenje ogromne količine nezarađenog, iz zemlje izniklog bogatstva (Salas, 2015: 78; Gallegos, 2016: 21-22, 75-76, 170). Venezuela će postati petro-država, u kojoj će generacije političkih lidera koristiti prihode od nafte za kupovinu socijalnog mira na unutrašnjem planu i povremeno aktivnu spoljnu politiku, a stanovništvo uživati blagodeti najjeftinijeg goriva na svetu te beneficiranog prevoza, komunalija, obrazovanja i zdravstva (Salas, 2015: 5, 7, 11; Gallegos, 2016: 23, 84; Mijares, 2017: 208; Ying-Hang To, Acuña, 2019: 135). Problem je samo u tome što bi za normalno funkcionisanje modernog društva, osim u potrošnju, nešto od prihoda moralo da ode i u proizvodnju, uključujući i proizvodnju samog resursa koji donosi bogatstvo. To se u Venezueli u poslednjih sto godina jedva dešava, usled čega ekonomija ove zemlje pokazuje simptome tipične za "holandsku bolest" - kad posedovanje prirodnog bogatstva uništi ostatak privrede, jer njene ostale grane postanu neisplative (Pantoulas, McCoy, 2019: 394; Ying-Hang To, Acuña, 2019: 134; Gallegos, 2016: 72-73, 82, 85-86; Salas, 2015: 66).

Ovde se potvrđuje prisustvo drugog elementa naše jednačine - latinoameričkog mentaliteta venezuelanske nacije, koja ne ume da upravlja svojim bogatstvom na način na koji to može, recimo, jedna protestantska Norveška (Gallegos, 2016: 112-113). No, latinoamerički segment ne iscrpljuje se u mentalitetu, već ga čini i geografski položaj unutar sfere uticaja - područja hegemonije Sjedinjenih Država. Dobar deo Latinske Amerike može da za svoj zaostali ekonomski i politički položaj - onako kako to čini npr. teorija zavisnosti - okrivi SAD, koje su svoje sebične hegemonističke interese stavljale iznad dobrobiti država i stanovništva regiona. Sredinom 20. veka činilo se da za Venezuelu to ne važi. Od političkog pakta Punto Fijo $1958 .^{2}$ pa sve do kraja 70 -ih Venezuela je imala izuzetne odnose sa Washingtonom, a da je u isto vreme - naravno, zahvaljujući naftnim prihodima - išla putem naizgled nezaustavljivog ekonomskog i političkog napretka. Država je bila konsolidovana demokratija sa stabilnim dvopartijskim sistemom. Razvila je kvalitetnu zdravstvenu zaštitu i obrazovanje, najbolju infrastrukturu u Južnoj Americi i visok nivo trgovine i investicija sa SAD (Naím, Toro, 2018: 126-127; Buxton, 2018: 8; Salas, 2015: 91-96). U vreme predsednika Rómula Betancourta (1959-1964) i Carlosa Andrésa Péreza (1974-1979) vodila je i vrlo aktivnu spoljnu politiku. Betancourt je nagovorio zemlje Bliskog istoka da formiraju OPEC i nateraju zapadne kompanije na raspodelu profita od nafte u korist države domaćina (Mijares, 2015: 76-77; Salas, 2015: 97; Gallegos, 2016: 77, 83). Pérez je, na talasu velikog skoka

2 Pakt Punto Fijo sklopile su 1958. tada najjače političke partije u Venezueli (bez komunista) da bi uspostavile stabilnu demokratsku vlast nakon svrgavanja diktatora Marcosa Péreza Jiméneza. 
cene nafte nakon naftne krize 1973, bio aktivan u Pokretu nesvrstanih, promovisao saradnju "Jug-Jug" i prednjačio u odnosu na SAD u pomaganju demokratizacije širom Latinske Amerike (Corrales, Romero, 2013: 18-19, 119; Ying-Hang To, Acuña, 2019: 127; Salas, 2015: 101-103). Washingtonu nisu smetala sporadična politička neslaganja sa Caracasom u kome su videle najvernijeg saveznika u regionu. ${ }^{3}$ Čak ni nacionalizacija nafte neće biti problem - američke kompanije će i nakon 1976. nastaviti nesmetano da posluju u Venezueli, a njena PDVSA će 1986. kupiti CITGO (Citgo Petroleum Corporation), američku kompaniju za preradu nafte (Corrales, Romero, 2013: 66-67; Salas, 2015: 104-105, 114).

Venezuelanska idila mogla je da traje dok je trajala i visoka cena nafte na svetskom tržištu, budući da nikakvu drugu osnovu nije imala. Štaviše, to ni u jednom trenutku nije bila jednaka idila za sve; visok nivo bogatstva od naftnih prihoda prikrivao je izuzetno nejednaku raspodelu tog bogatstva - sedamdesetih godina Venezuela je imala najveći nacionalni dohodak po glavi stanovnika, ali i jednu od najvećih stopa nejednakosti u Latinskoj Americi (Salas, 2015: 106-107). Zato je bilo neminovno da se sa padom cene nafte osamdesetih godina teret krize sruči pre svega na leđa siromašnih. Oni su do tada uživali makar nekakve beneficije, pre svega jeftin prevoz i pristup obrazovanju (ibid.: 118). Nakon devalvacije bolivara (venezuelanske nacionalne valute) 1983. Venezuela postepeno počinje da uvodi neoliberalne mere po modelu MMF, što će kulminirati vrlo teškim paketom mera za koje se Pérez odlučuje kada 1989. bude ponovo izabran za predsednika. Njega je narod izabrao u nadi da će vratiti vreme blagostanja iz sedamdesetih, a on sam se u toku kampanje protivio neoliberalnim merama. Izneverivši obećanje po stupanju na dužnost, prvo što su njegove mere pogodile bila je cena goriva, odnosno javnog prevoza, koja je udvostručena. Ovo će dovesti do masovne narodne pobune u siromašnim predgrađima Caracasa, vanrednog stanja i pogibije nekoliko stotina ljudi u obračunu sa snagama bezbednosti - događaj koji će ostati upamćen kao "Caracazo masakr", a nakon koga će se Venezuelanci trajno razočarati u dotadašnji politički sistem i njegove kapacitete da rešava društvene probleme (Kovalik, 2019: 39-41, 53-54; Salas, 2015: 110-120; Gallegos, 2016: 88-90). Siromaštvo će se u toku 80-ih uvišestručiti i u narednoj deceniji nastaviti da raste, paralelno sa nastavkom sprovođenja neoliberalnih mera, otvaranjem naftnog sektora prema stranim kompanijama i slomom bankarskog sistema u vreme Pérezovog naslednika Rafaela Caldere (Salas, 2015: 121-122, 126-130; Gallegos, 2016: 91, 94). ${ }^{4}$

${ }^{3}$ Ovo savezništvo počelo je još 1902, kada su Nemačka i Britanija pod pritiskom SAD obustavile blokadu venezuelanskih luka zbog neplaćenih dugovanja Venezuele prema njima. Tada je Theodore Roosevelt proširio značenje Monroeove doktrine pozivanjem na pravo SAD da budu "policajac" u regionu i isključe Evropljane (Salas, 2015: 51-54).

4 Sam Pérez je opozvan zbog pronevere novca. 
Ubrzo su se javile i jasne političke posledice. Venezuela ima bogatu istoriju pučeva. Februara 1992. po prvi put će biti pokušan puč, ne od strane desničarskih snaga koje bi štitile privilegije bogatih klasa, već od levičarskog MBR (Movimiento Bolivariano Revolucionario - Revolucionarni bolivarski pokret), na čijem čelu se nalazio potpukovnik Hugo Rafael Chávez Frías. Puč, koji je imao za cilj hapšenje Péreza, neće uspeti, jer mu se neće pridružiti dovoljan broj vojnih jedinica iz Caracasa. Chávez će priznati poraz, pozvati saborce da se predaju i provesti u zatvoru dve godine, dok ga Caldera ne pusti (Kovalik, 2019: 52-53; Salas, 2015: 122-123, 125-128). Hugo Chávez je poticao iz siromašne porodice, mešanog rasnog sastava i ruralnog područja. Za vojnu akademiju se odlučio jer je ljudima poput njega to bila najbolja prilika za napredovanje na društvenoj lestvici (Kovalik, 2019: 58; Salas, 2015: 123-124). Isprva u jedinici zaduženoj za suzbijanje pobuna, vrlo brzo će doći u dodir sa levim idejama. Proučavajući istoriju Venezuele, Chávez je video vojsku kao potencijalnog subjekta društvene promene (Salas, 2015: 124). Sanjao je o tome da dovrši posao "Velikog oslobodioca" iz 19. veka, Simóna Bolívara, tako što bi oslobodio Venezuelu i ostatak Latinske Amerike od dominacije SAD, kao i siromašni narod od bogatih klasa (Kovalik, 2019: 54-55). " "Caracazo" je bio prekretnica u privlačenju regruta za novi pokret, a narastajuće nezadovoljstvo raznih segmenata društva aktuelnim političkim sistemom i ekonomskom situacijom u Venezueli 90-ih doneće Chávezu ubedljivu pobedu nad Henriqueom Salasom Römerom na predsedničkim izborima 1998. - sa 56 posto glasova (Salas, 2015: 125-135). Nakon njegove inauguracije naredne godine biće usvojen i novi ustav, a Republika Venezuela preimenovana u Bolivarsku Republiku Venezuelu (Kovalik, 2019: 54-55). Počela je istorija čavizma, koja će se, osim radikalnim promenama u društvenom, ekonomskom i političkom sistemu Venezuele, odlikovati i temeljno drugačijim odnosima Caracasa i Washingtona.

Kako su i zašto SAD dozvolile da im se Venezuela od najvernijeg i najvrednijeg latinoameričkog saveznika preko noći pretvori u spoljnopolitički problem? Najpre, venezuelansko-američko savezništvo u startu ne bi trebalo preceniti - radi se o dvema po gotovo svemu različitim državama, sa različitim unutrašnjim društvenim imperativima i spoljnopolitičkim prioritetima. U temelju ovog savezništva, kako smo videli, nalazila se nafta, ali ona nije donosila jednaku korist obema stranama, kao ni različitim društvenim slojevima u samoj Venezueli. SAD nisu na vreme

${ }^{5}$ Ono što je izdvajalo Bolívara od drugih lidera borbe za oslobođenje latinoameričkih španskih kolonija bila je kontinentalna vizija - osim stvaranja "Velike Kolumbije" (današnji Ekvador, Kolumbija i Venezuela), on je maštao o ujedinjenoj Latinskoj Americi ("Velikoj otadžbini"), koja bi parirala Evropi i SAD (Salas, 2015: 31-34). U Bolívarovom nasleđu, dakle, možemo da nađemo korene kasnije aktivne spoljne politike Venezuele u regionu, koja će kulminirati u vreme Cháveza. 
uočile potencijal za društvene i političke promene u Venezueli, koji će narasti jednom kad sa padom cene nafte ove nejednakosti postanu nepodnošljive. Drugo, kraj Hladnog rata dao je Sjedinjenim Državama lažan osećaj sigurnosti sopstvene hegemonije na zapadnoj hemisferi (Ciccarilo, 2016: 25, 28). Nisu na vreme shvatile da Istočna Evropa, koja je jedva čekala da se oslobodi komunističke tiranije i pobegne u neoliberalni kapitalizam, i Latinska Amerika, koju je taj isti neoliberalni kapitalizam već dve decenije pustošio, nisu isto. Zaokret ka levici u posthladnoratovskoj Latinskoj Americi bio je upravo posledica neuspeha neoliberalnih reformi da poprave ekonomsku situaciju i smanje siromaštvo i socijalne razlike, a taj neuspeh nije iskompromitovao samo ekonomski sistem, već i američko regionalno vođstvo (Gill, 2018a: 74-79; Pavlova, 2018: 398). Na to da baš Venezuela povede ovaj levičarski trend, uticala su četiri činioca. Prvi je pomenuto precenjivanje venezuelansko-američkog savezništva, odnosno naviknutost Washingtona da Venezuela stabilno operiše u njegovoj orbiti (Salas, 2015: 9). Drugi je nostalgija Venezuelanaca za boljim životom iz 70-ih, veća nego bilo gde u Latinskoj Americi. Treći je odsustvo proganjanja radikalne levice u demokratskoj Venezueli (za razliku od nekih latinoameričkih diktatura), a četvrti snaga vojske kao institucije, koja nije narušila reputaciju vođenjem "prljavih ratova" ili vojnim huntama kao drugde u regionu (Corrales, Romero, 2013: 124). Da vidimo kako će se Chávez snaći u svom izazovu regionalnom hegemonu, i kako će mu ovaj odgovoriti.

\section{Nafta kao pokretač i kočnica čavističkog izazova}

Hugo Chávez je rešenje za probleme venezuelanskog društva video u radikalnoj transformaciji ekonomskog i političkog sistema, kao i spoljnopolitičke orijentacije. U startu je, međutim, napravio grešku - poput svojih prethodnika, za ispunjenje zadatih ciljeva oslonio se na naftu. Ni on, kao ni svi venezuelanski lideri u poslednjih 100 godina, nije shvatao da je zavisnost od nafte problem, a ne rešenje. Lično će imati sreće, jer će u toku njegove vladavine doći do ogromnog porasta cene nafte na svetskom tržištu - sa nepunih 10 dolara 1998. ona će do 2008. skočiti na 133 dolara za barel (Mijares, 2015: 77). To će Cháveza samo učvrstiti u zabludi da pomoću naftnih prihoda može da izgradi "socijalizam 21. veka" i proširi ga širom Latinske Amerike, a ta zabluda će se posle njegove smrti pokazati pogubnom za Venezuelu. Što se tiče Sjedinjenih Država, njima svakako nije bilo milo što se u njihovom "dvorištu" pojavio radikalni socijalista i antiamerički orijentisan lider, ali će ga u početku uglavnom ignorisati, da bi vremenom Chávez postao najveći izazov za Washington u Latinskoj Americi nakon Hladnog rata (Corrales, Romero, 2013: 40-46). Izazov koji, međutim, nijednog trenutka za vreme Chávezovog života neće preći jednu bitnu granicu - niti će to SAD učiniti u odgovoru na taj izazov - a to je prekid u trgovini naftom, koja će još neko vreme ostati “jedan od najkompatibilnijih i najmeđuzavisnijih trgovinskih odnosa u svetu” (ibid.: 65-66). 
Bolivarski ustav iz 1999. usvojen je sa 72 posto glasova na referendumu. Venezuela je proglašena za multietničku i plurikulturnu državu, uz uvećanje prava domorodačkog stanovništva i žena. Ustanovljena je jednodomna skupština, uvedena funkcija potpredsednika, a predsednički mandat povećan na 6 godina. Uvedene su institucije građanske moći - tzv. participativne demokratije, koja će funkcionisati kroz komunalne savete građana. Po svom slovu, ovaj ustav je bio jedan od najnaprednijih na svetu (Salas, 2015: 136-139, 167-168). U praksi je, međutim, načinjen zaokret ka autoritarizmu i ukidanju kočnica i ravnoteža centralizovanoj i ideologizovanoj vlasti. Vojska je dobila veću ulogu u državi nego što je imala u prethodnih pola veka i stavljena je u službu vladajuće partije. Vrhovni sud takođe je napunjen partijskim kadrovima. Efektivna podela vlasti je gotovo nestala (Briceño-Ruiz, 2019: 183; Corrales, Romero, 2013: 132-134). Posledica je bila preuzimanje kontrole države nad velikim delom privrede, nacionalizacijama i postavljanjem ljudi na upravljačka mesta po kriterijumu lojalnosti, a ne kompetentnosti (Naím, Toro, 2018: 130; Corrales, Romero, 2013: 79). To se najbolje videlo u PDVSA, koja je napunjena ideološkim kadrovima, čime je u potpunosti ukinuta njena autonomija od politike i mogućnost da izbegne deo plaćanja državi (Corrales, Romero, 2013: 135137; Gallegos, 2016: 94-95). Sve ovo će doprineti kasnijoj ekonomskoj katastrofi, ali bi do nje svakako došlo i da nisu uvedene socijalističke mere, jednom kada cena nafte padne - jer je, kao što smo videli, zavisnost od nafte primarni uzrok nestabilnosti venezuelanske ekonomije, a ona je postojala i mnogo pre Chávezovog socijalizma. Chávez je samo reciklirao neuspešne ekonomske politike svojih prethodnika - prihodi od nafte su se nemilice trošili, a nije se ulagalo u proizvodnju; ona je opala za 25 posto, ali je zato uvoz hrane eksponencijalno porastao (Gallegos, 2016: 3940, 95-96, 98-99, 153; Caldwell, 2019: 8, 11).

Ipak, dok je cena nafte bila visoka, Chávezov sistem je funkcionisao i isporučivao rezultate. Valja reći da ni radikalne autoritarne i socijalističke mere nisu bile odmah uvedene. Program s kojim je Chávez izabran za predsednika nije bio čisto antitržišni poput nekadašnjeg sovjetskog socijalizma, niti je u političkom smislu težio da bude poput aktuelnog kubanskog sistema, već je naglašavao ravnotežu između države i tržišta (Buxton, 2018: 13-14). Nacionalizacija koju je izveo bila je delimična. Strane naftne kompanije, uključujući i američke, nisu proterane iz Venezuele, već je na njih primenjen novi zakon koji je propisivao da u svakom zajedničkom projektu PDVSA mora da ima većinski udeo (Antonopoulos, Cottle, 2017: 53-54; Gallegos, 2016: 97). Chávez je dobio nekoliko relativno slobodnih i poštenih izbora, a na ustavnom referendumu 2007. čak je izgubio; Venezuela je među prvim državama u kojima je uvedeno poluelektronsko glasanje (Kovalik, 2019: 68-70; Gill, 2018b: 307). Autoritarni zaokret započeo je nakon neuspelog puča 2002, a potpuna čistka u PDVSA nakon naftnog štrajka 2003. (Gallegos, 2016: 95). U deceniji 
koja je sledila, siromaštvo u Venezueli je redukovano sa 49 na 25, a ekstremno sa 21 na 7 posto (Gill, 2018b: 308). Pored toga, siromašni su kroz naftnim prihodima finansirane socijalne programe - misije - dobili mnogo veći pristup subvencionisanoj hrani te unapređenom obrazovanju, zdravstvu i stambenim uslovima (Kovalik, 2019: 58-62; Salas, 2015: 192-200; Gill, 2018b: 308-309). Zakonom o zemljištu je neobrađivana zemlja oduzeta veleposednicima i podeljena siromašnim farmerima (Gallegos, 2016: 93). Chávezovi kritičari su u pravu kada tvrde da za pozitivne socijalne rezultate nije zaslužna njegova ekonomska politika, već rast cene nafte (Caldwell, 2019: 8; Gallegos, 2016: 97). Ali, to ne umanjuje činjenicu da njegovi prethodnici nisu uspeli da ih ostvare kada su imali jednako povoljne uslove, odnosno da je rapidno uvećanje socijalnog raslojavanja nastupalo uvek kada bi ti uslovi postali nepovoljni.

Još nas više zanima način na koji je Chávez trošio naftne prihode za vođenje ne samo aktivne, već hiperaktivne spoljne politike, što će i izazvati problem između Venezuele i SAD. Chávezova spoljna politika imala je tri osnovna cilja: potvrdu nacionalnog suvereniteta i međunarodnog statusa Venezuele; širenje ideologije van granica Venezuele, kako bi se izmenila ideološka orijentacija država regiona; integraciju Latinske Amerike kako bi se ona otrgla dominaciji SAD i zauzela odgovarajuću poziciju u multipolarnom svetskom poretku u nastajanju (Romero, Mijares, 2016: 182; Mijares, 2017: 209-210; Corrales, Romero, 2013: 174-175; Pavlova, 2018: 398; Sitenko, 2016: 44). Zapravo je u ostvarivanju ovih ciljeva, pored rasta cene nafte, Venezueli pomogao i očigledni porast multipolarnosti u prvoj deceniji 21. veka, a i mogućnost uspostavljanja veza sa rivalima SAD na globalnom planu, poput Rusije i Kine, ali i “otpadničkim državama” kao što je Iran (Romero, Mijares, 2016: 187-188; Mijares, 2015: 78). Radikalni antiamerikanizam, koji je Chávezova Venezuela potvrđivala vezama s ovim akterima, bio je za nju više od spoljne politike - postao je identitetsko pitanje (Corrales, Romero, 2013: 163-165, 170-171). Chávez je u prvih nekoliko godina vlasti uspeo da izgradi identitet predvodnika latinoameričke levice i otpora hegemoniji SAD.

Ključni element venezuelanske spoljne politike toga doba bio je zato na regionalnom planu. Osim za socijalne programe kod kuće, Chávez je obilato koristio naftu i prihode od nje za tzv. diplomatiju socijalne moći - nastojanja da se što novcem, što privlačnošću ideologije prikaže kao prijatelj siromašnih i borac za razvoj i jednakost širom Latinske Amerike (ibid.: 17, 34-36). Finansijsku i diplomatsku pomoć pre svega je usmeravao sličnomislećim političkim pokretima i vladama. Logično, počeo je sa Kubom, potpisivanjem sporazuma o saradnji 2000. godine, koji je podrazumevao prodaju venezuelanske nafte Kubi po jako subvencionisanoj ceni u zamenu za kvalifikovanu radnu snagu koja je Venezueli nedostajala, pre svega u oblasti vojske, obaveštajnog sektora, obrazovanja i posebno zdravstva - u Venezu- 
elu će uskoro početi da pristiže na hiljade kubanskih lekara (ibid.: 26-27, 171). Po sličnom modelu, podrška manje ili više radikalnim i u odnosu na spoljnu politiku SAD kritičnim levičarskim pokretima dovešće do tzv. "ružičaste plime", tj. talasa dolazaka na vlast socijalističkih i socijaldemokratskih snaga širom regiona: Daniel Ortega u Nikaragvi, Evo Morales u Boliviji, Rafael Correa u Ekvadoru i Fernando Lugo u Paragvaju došli su na vlast uz neposrednu pomoć Venezuele, koja je pomagala i Manuela Zelayu u Hondurasu, Kirchnere (Cristinu i Néstora Kirchner) u Argentini, Lulu da Silvu i Dilmu Rousseff u Brazilu, kao i još niz levih lidera koji će preplaviti Latinsku Ameriku početkom 21. veka (Buxton, 2018: 16-17; Corrales, Romero, 2013: 24-25; Salas, 2015: 144). Veze sa novim ideološki bliskim vladama ojačane su i formalizovane kroz nekoliko mehanizama regionalne integracije koje je Venezuela pokrenula: ALBA (Alianza Bolivariana para los Pueblos de Nuestra América - Bolivarski savez za narode naše Amerike, politički mehanizam etatističkih ekonomija, u koji će pored Venezuele i Kube ući Ekvador, Nikaragva, Bolivija i nekoliko manjih karipskih država), PetroKaribe (Petrocaribe - ekonomska komponenta ALBA, preko koje je njenim članicama isporučivana subvencionisana nafta u zamenu za različita dobra i usluge), UNASUR (Unión de Naciones Suramericanas, pokušaj objedinjavanja južnoameričkih država, uz stvaranje Banke juga), CELAC (Comunidad de Estados Latinoamericanos y Caribeños, još šira zajednica latinoameričkih i karipskih država); formirana je i TeleSur, regionalna tv mreža socijalističkih država, kao i virtuelna valuta SUCRE (Romero, Mijares, 2016: 180; Mijares, 2015: 78-79; Buxton, 2018: 17; Antonopoulos, Cottle, 2017: 50; Corrales, Romero, 2013: 24, 27; Kovalik, 2019: 55-56; Salas, 2015: 145-146, 151).

Ipak, izgradnja radikalnog antiameričkog identiteta Venezuele nije išla glatko, jer je imala dosta protivnika na unutrašnjem planu. Chávezov socijalizam se dogodio u zemlji gde su kapitalističke vrednosti bile duboko ukorenjene, kao i veze srednjih i viših slojeva sa SAD, koje su za te slojeve bile više od međunarodnih odnosa - imale su poseban simbolički i kulturni značaj (Salas, 2015: 6, 141). Krajem 2001. konzervativna opozicija započinje proteste protiv Chávezovih reformskih zakona u oblasti nafte i poljoprivrede (ibid.: 154). Oni kulminiraju pučem u aprilu 2002. kada opoziciono orijentisani deo vojske zarobljava Cháveza na ostrvu Orchila, a šef privredne komore Pedro Carmona se proglašava za predsednika, da bi već kroz dva dana deo vojske odan Chávezu izveo novi puč, oslobodio Cháveza i vratio ga na vlast (ibid.: 154-157; Kovalik, 2019: 121-122; Mijares, 2017: 210). Sjedinjene Države su podržale puč i bile spremne da priznaju Carmonu za predsednika, ali su ustuknule nakon što je Chávez vraćen na vlast, a ispostavilo se i da latinoameričke države nisu imale nameru da ih slede u priznanju puča (Corrales, Romero, 2013: 48-50; Salas, 2015: 157). Krajem 2002. započinje nova destabilizacija u Venezueli uz podršku SAD - lideri PDVSA i naftnih sindikata stupaju u generalni štrajk, s 
idejom da uskrate Chávezu prihode od nafte. Nakon dva meseca štrajk propada, jer su njegove vođe potcenile nivo podrške naftnih radnika i stanovništva Chávezu, ali i pomoć vladi iz inostranstva (brazilski predsednik da Silva je u toku krize poslao naftu Venezueli da bi joj nadoknadio nestašicu) (Salas, 2015: 158-160). Nakon neuspeha opozicije da smeni Cháveza na referendumu o opozivu 2004, ovaj napokon uspeva da stabilizuje vlast (ibid.: 160-162).

Chávez je zapravo prvi put ozbiljnije "naljutio" SAD nakon 11. septembra 2001, kad je bio jedan od retkih svetskih lidera koji nije podržao njihov napad na Afganistan (Buxton, 2018: 15-16; Corrales, Romero, 2013: 48; Gill, 2018a: 81-84). Washington od tada asertivnije nastupa prema Venezueli, tako da nije neobično da je u njenoj unutrašnjoj destabilizaciji video priliku da blagovremeno skloni Cháveza s vlasti, te je podržao opozicione snage, što će nastaviti da čini do danas. Autor ove asertivne politike bio je glavni diplomata za Latinsku Ameriku predsednika Georgea W. Busha Otto Reich (Corrales, Romero, 2013: 48-49). Ovo je, međutim, samo dodatno radikalizovalo Cháveza, te SAD i Venezuela ulaze u period od nekoliko godina zaoštravanja uzajamne retorike i akcija (Buxton, 2018: 16; Corrales, Romero, 2013: 47). Washingtonu nije bilo samo po sebi problematično to što je Chávez nakon štrajka uspostavio još čvršću kontrolu nad naftom, već ciljevi za koje je naftu koristio. Integracioni procesi u Latinskoj Americi koje je pokrenuo, a koji su kulminirali projektom virtuelne valute SUCRE, sa ciljem da ona istisne američki dolar iz regiona, bili su ozbiljna pretnja za američki kapitalizam i regionalnu hegemoniju (Antonopoulos, Cottle, 2017: 50, 54-55). Kao odgovor, SAD promovišu sopstvene bilateralne veze i integracije u Latinskoj Americi, pre svega jačanjem odnosa sa Kolumbijom, ali i umerenim levičarskim vladama, kao i potpisivanjem nekoliko sporazuma o slobodnoj trgovini (Corrales, Romero, 2013: 52; Salas, 2015: 143). ${ }^{6} \mathrm{Na}$ napore Venezuele da ostvari vojnu nezavisnost (ranije su joj SAD bile glavni snabdevač naoružanja i vojne opreme) i modernizuje vojsku u saradnji sa novim partnerima, Washington odgovara vojnim sankcijama (Corrales, Romero, 2013: 21, 53). Žestoki iritanti u odnosima SAD i Venezuele postaju i porast trgovine drogom preko Venezuele (odnosno izbegavanje Caracasa da sarađuje s Washingtonom na planu borbe protiv narkotika) te veze Cháveza s "otpadničkim" državama, posebno Iranom (gde posebnu pažnju Washingtona privlače transferi oružja, novca i ljudi između Irana i Venezuele u svrhu podrške Iranu bliskoj vojnoj organizaciji Hezbolahu) (ibid.: 22-24, 29-31, 166).

Pa ipak, sukob ne izmiče kontroli. Naprotiv, nakon nekoliko godina žestoke razmene retorike i aktivnosti, počev od 2007. Venezuela i SAD uspostavljaju kak-

${ }^{6}$ Nije izostala ni promena politike režima s kojima je Chávez bio blizak. Prve "žrtve" bile su predsednik Haitija Jean-Bertrand Aristide i predsednik Hondurasa Manuel Zelaya (Kovalik, 2019: 132-142). 
vu-takvu koegzistenciju, zahvaljujući pomalo iznenadnoj promeni pristupa Washingtona. Pod rukovodstvom pomoćnika državnog sekretara Thomasa Shannona, Jr. (koga će novi predsednik Barack Obama kasnije postaviti za ambasadora u Brazilu) započeta je politika "pričaj tiho, sankcioniraj meko", koja je podrazumevala uzdržavanje od uzvraćanja na Chávezovu zapaljivu retoriku, umanjivanje političke pretnje koja dolazi od Venezuele, fokusiranje na oblasti u kojima dve zemlje mogu da sarađuju, blage sankcije (Corrales, Romero, 2013: 56-57, 92-98). Koegzistencija i pokušaj prilaženja Venezueli dodatno će biti naglašeni sa dolaskom Obame na položaj predsednika. ${ }^{7}$ Kako objašnjavamo to što sukob SAD i Venezuele, i pored realnih osnova za neprijateljstvo, nije eskalirao, već je u periodu 2007-2012. stavljen pod kontrolu? Objašnjavamo to istim činiocem koji je u ranijoj istoriji odnosa Venezuele i SAD pogodovao njihovom savezništvu, a zatim postao i pokretač Chávezove hiperaktivne antiameričke spoljne politike - naftom.

Za sve vreme Chávezove vladavine, uprkos dodatnom smanjenju prostora za aktivnost američkih kompanija, naftna međuzavisnost SAD i Venezuele je opstala. Caracas, i pored velikog truda da to učini, ${ }^{8}$ nije uspeo da diverzifikuje izvoz i američko tržište zameni kineskim, niti je Washingtonu mogla da bude isplativija nafta sa Bliskog istoka - geografska blizina SAD i Venezuele učinila je svoje (Romero, Mijares, 2016: 182-183; Mijares, 2015: 78; Antonopoulos, Cottle, 2017: 50; Corrales, Romero, 2013: 66, 71-72). ${ }^{9}$ I ne samo to - međuzavisnosti je doprinosila i američka kompanija CITGO, u vlasništvu PDVSA, koja je jedina posedovala tehnologiju za rafinisanje, inače guste, venezuelanske nafte (Corrales, Romero, 2013: 67-71). Naftna međuzavisnost ispostaviće se kao kočnica američko-venezuelanskog sukoba, s jedne strane sputavajući Cháveza da uvede naftni embargo Sjedinjenim Državama i tako sa oštrih reči pređe na dela - kidanje svih veza sa Washingtonom, a s druge utičući na oportunističke SAD da se uzdrže od ozbiljnijeg kažnjavanja Caracasa koje bi imalo za cilj promenu režima. Zaključno s 2013. godinom, čavistički izazov ostaće za SAD pretnja srednjeg nivoa (ibid.: 4-5, 12, 74, 76).

Ublažavanje američkih poteza prema Venezueli Chávez će iskoristiti za jačanje svog položaja u zemlji. Iako je 2007. doživeo poraz na ustavnom referendumu, 2009. će ipak uspeti da "progura" promene ustava koje uvode nove socijalističke koncepte i ukidaju ograničenje broja predsedničkih mandata (Salas, 2015: 202-203).

${ }^{7}$ Aludirajući na svoj raniji govor u Generalnoj skupštini UN, kada je Busha nazvao đavolom i rekao da se u sali nakon njegovog nastupa oseća miris sumpora, Chávez je 2009. Obamu prokomentarisao sa "više ne miriše na sumpor... miriše na nadu" (Corrales, Romero, 2013: 20, 99).

${ }^{8}$ Kad je Chávez došao na vlast, Venezuela nije prodavala naftu Kini, a 2012. joj je prodavala 600 hiljada barela dnevno (Salas, 2015: 150).

9 Tankeru od Venezuele do SAD treba 5 dana, a sa Bliskog istoka do SAD, odnosno od Venezuele do Kine, 30-40 dana. 
Odoleće i novoj opozicionoj koaliciji MUD (Mesa de la Unidad Democrática "Sto demokratskog jedinstva") i njenom kandidatu Henriqueu Caprilesu koga pobeđuje na izborima 2012. (ibid.: 203-206). Ipak, neće moći da odoli sopstvenoj smrtnosti, te nikad neće preuzeti novi mandat. Još 2011. objavio je da ima rak i da ide na lečenje na Kubu; sopstvenoj inauguraciji nije ni prisustvovao, a 5. marta 2013. umire, nakon što je prethodno odredio ministra spoljnih poslova Madura za svog naslednika (ibid.: 206-207; Mijares, 2017: 212). S Chávezom neće umreti i čavizam kao ideologija, odnosno čavistički izazov Sjedinjenim Državama. Ono što, međutim, hoće odumreti - kako će se ispostaviti, u roku od svega godinu dana - jeste miroljubiva koegzistencija SAD i Venezuele.

\section{Kriza: vrhunac, ili napuštanje naftne logike u venezuelansko-američkim odnosima?}

Dosadašnje izlaganje je pokazalo da se venezuelanska spoljna politika odlikuje velikom zavisnošću od cikličnog kretanja cene nafte - bez visoke cene i mogućnosti države da ostvaruje prihode od nafte nema ni ambiciozne spoljne politike. Ograničenje spoljnopolitičkih ciljeva postaće imperativ novog venezuelanskog predsednika Madura od drastičnog pada cene nafte na svetskom tržištu u junu 2014. (Romero, Mijares, 2016: 166, 190). I neće samo spoljna politika stradati - Venezuela će se suočiti sa možda i najvećom ekonomskom krizom u svojoj istoriji, koja će ubrzo prerasti u političku, čije se rešenje u trenutku pisanja ovog rada još uvek ne nazire. Na drugoj strani, u politici Sjedinjenih Država prema Venezueli, nastupiće novi preokret $\mathrm{u}$ asertivnom pravcu, najpre $\mathrm{u}$ drugom mandatu Obame, a zatim naročito nakon što Donald Trump postane predsednik. Što se više kriza u Venezueli bude produbljivala i vezivala ruke njenom rukovodstvu i na spoljnom i na unutrašnjem planu, to će američko neprijateljstvo prema njemu biti izrazitije, a potezi usmereni na njegovo svrgavanje ozbiljniji i konkretniji. I to sve uprkos - a možda baš zahvaljujući - naftnoj međuzavisnosti.

Maduro, koji je nekada radio kao vozač autobusa, a važio je za jednog od ideološki najtvrđih članova Chávezove administracije i "kubanskog čoveka", potvrđen je za predsednika na izborima održanim ubrzo nakon Chávezove smrti, na kojima tesno (1,5 posto glasova razlike) pobeđuje Caprilesa (Salas, 2015: 207-210). Prvi problem s kojim se suočio bilo je odsustvo harizme koju je imao Chávez, što će mu u početku stvoriti problem autoriteta, pre svega kod vojnih krugova. Taj problem će rešavati u hodu, upravo uz pomoć svojih prijatelja Kubanaca, čija će tajna služba svojim agentima premrežiti venezuelansku armiju, a to će se u kasnijoj krizi pokazati odlučujućim činiocem lojalnosti vojske Maduru (Mijares, 2015: 80; Naím, Toro, 2018: 127; Ellis, 2017a: 24). Drugi problem je pomenuta ekonomska kriza. Njene razmere biće stravične. U prvih pet godina Madurove vladavine, venezuelan- 
ski BDP je u najmanju ruku prepolovljen, siromaštvo je naraslo na preko polovine stanovništva (dakle iznad nivoa na kome je bilo pred Chávezov dolazak na vlast), inflacija je dostigla milionsku cifru, nastupila je hronična nestašica osnovnih potrošačkih dobara, problemi u funkcionisanju električne mreže, poteškoće zdravstvenog sistema i ostali katastrofalni pokazatelji (Naím, Toro, 2018: 134-135; Pantoulas, McCoy, 2019: 393-396; Bahar, Piccone, Trinkunas, 2018: 3-4; Caldwell, 2019 : 5; Gallegos, 2016: 47, 51-52, 99). Situacija se neće bitno popraviti ni nakon 2016, kada cena nafte ponovo poraste, jer je njena proizvodnja u međuvremenu dodatno opala (Pantoulas, McCoy, 2019: 394-395; Bahar, Piccone, Trinkunas, 2018: 3). Treći Madurov problem biće preokretanje političke orijentacije u regionu. "Ružičastu plimu" u drugoj deceniji 21. veka smenjuje talas dolazaka na vlast desničarskih i prowashingtonskih snaga u nizu država Latinske Amerike, između ostalih i u nekim od najbližih saveznika Venezuele, poput Ekvadora i Kolumbije, ali i u regionalnim silama kao što su Brazil i Argentina (Buxton, 2018: 18; Campos, Prevost, 2019: 14; Kovalik, 2019: 146-150). Ovu novu "plimu" podstakao je pad popularnosti levice između ostalog usled onoga što je u regionu viđeno kao neuspeli čavistički projekat (Corrales, Romero, 2013: 178-179; Ellis, 2019: 77).

Pad cene nafte nije pogodovao nastavku ambiciozne spoljne politike, ali jeste uticao na dodatnu centralizaciju moći i porast autoritarizma u samoj Venezueli (Romero, Mijares, 2016: 167). Prvi nasilni opozicioni protesti protiv represije vlasti počeli su već nakon Madurovog izbora za predsednika 2013. (koji opozicija nije priznala kao slobodan i pošten), da bi se obnovili 2014, ukupno odnevši na desetine žrtava i rezultiravši hapšenjem nekoliko lidera opozicije (Leopolda Lópeza, Maríe Corine Machado i Antonia Ledezme) (Kovalik, 2019: 78; Salas, 2015: 213-214; Briceño-Ruiz, 2019: 185). Iznenađujuće velik uspeh opozicija postiže na izborima za Nacionalnu skupštinu 2015, osvojivši dvotrećinsku većinu mandata. Vrhovni sud, inače napunjen režimskim lojalistima u periodu trajanja mandata prethodnog saziva Skupštine, najpre je osporio opoziciji nekoliko poslanika, da bi marta 2017. i formalno (doduše privremeno) oteo Skupštini zakonodavne prerogative (BriceñoRuiz, 2019: 186; Antonopoulos, Cottle, 2017: 61). To je, zajedno sa katastrofalnom ekonomskom situacijom, bilo okidač novih protesta, najmasovnijih do tada, koji traju od aprila do avgusta 2017. i odnose blizu 200 života (Briceño-Ruiz, 2019: 186; Antonopoulos, Cottle, 2017: 50-52). Madura protesti nisu pokolebali - nastavljajući autoritarni zaokret, konstituisao je Ustavotvornu skupštinu koja bi u potpunosti preuzela nadležnosti Nacionalne, te ostvario dobar rezultat na prilično neregularnim lokalnim izborima na jesen. Nakon neuspeha pregovora sa opozicijom u Dominikanskoj Republici - koji su mu očigledno poslužili kao sredstvo za zaustavljanje protesta - Maduro raspisuje prevremene predsedničke izbore za maj 2018. Dobija ih više nego ubedljivo (68 posto glasova), ali uz bojkot većeg dela opozicije i nepri- 
znavanje od strane 50-ak država (Pantoulas, McCoy, 2019: 398-400; Buxton, 2018: 9; Antonopoulos, Cottle, 2017: 63-64; Briceño-Ruiz, 2019: 186-187).

Ekonomska situacija je u 2018. nastavila da se pogoršava, a pratila ju je izbeglička kriza - što zbog siromaštva, što zbog represije vlasti i nestabilne političke situacije u zemlji, Venezuelu je napustilo oko 3 miliona ljudi, koji su utočište uglavnom nalazili u susednim zemljama (najviše Kolumbiji, oko polovine od toga broja) (Bahar, Piccone, Trinkunas, 2018: 4-5; Caldwell, 2019: 6). Avgusta 2018. izveden je neuspeli oružani napad na Madura dronom, što dovodi do novog talasa represije, ali započinju i novi protesti, koji uskoro, imajući u vidu njihovu pretežnu ekonomsku i socijalnu motivisanost, postaju još masovniji od prethodnih (Pantoulas, McCoy, 2019: 397-398, 401-402). Privremeno dezorijentisana opozicija napokon uspeva da se konsoliduje kada Juan Guaidó januara 2019. dolazi na čelo Nacionalne skupštine, a zatim, u konsultacijama sa svojim mentorom Leopoldom Lópezom, odlučuje da se proglasi za predsednika, pozivajući se na nekoliko odredbi venezuelanskog ustava (ibid.: 404; Briceño-Ruiz, 2019: 180). ${ }^{10}$ Nakon tri meseca vrlo oštre predsedničke krize, na ivici građanskog rata, a sa kulminacijom u neuspelom puču aprila 2019, nastupa pat pozicija, koja do trenutka pisanja ovog rada već traje punih godinu dana. Maduro je, uprkos izuzetnoj nepopularnosti kod stanovništva, uspeo da opstane na vlasti, pre svega zahvaljujući lojalnosti najvećeg dela vojske i pročavističkih neregularnih oružanih grupa, tzv. kolektivosa (Briceño-Ruiz, 2019: 188; Buxton, 2019: 130; Gallegos, 2016: 117).

Pat poziciju nije toliko odredio odnos snaga u samoj Venezueli koliko inostrana reakcija na njenu krizu. Preko 50 država sveta - među njima i SAD i većina latinoameričkih država - eksplicitno je priznalo Guaidóa za venezuelanskog predsednika, što je Madura stavilo u tešku situaciju. Ipak, do šah-mat pozicije po njega još uvek nije došlo, i to pre svega zahvaljujući činjenici da SAD, i pored dvogodišnjih pretnji, nisu oružano intervenisale da ga obore. Objašnjenje izostanka američke intervencije, koja je početkom 2019. delovala vrlo izvesno, zahteva prethodnu analizu načina na koji su SAD i Venezuela uopšte došli u situaciju da se takva opcija nađe na stolu. Odgovor zašto je Washington pred kraj Obaminog, a naročito u vreme Trumpovog mandata napustio koegzistenciju i odlučio se na eskalaciju protiv Venezuele, zapravo je relativno jednostavan. Presedan za to smo već videli prilikom neuspelog puča 2002, koji su SAD podržale, a zatim pomogle i naftni štrajk - i uopšte u narednih nekoliko godina vodile relativno asertivnu politiku protiv Caracasa, iako su ga prvobitno ignorisale. Taj puč je otkrio prve slabosti Chávezove pozicije - što će biti signal za SAD da stegnu obruč oko njega i, ako je moguće, završe s njim kad im se već pruža prilika. Slično će se dogoditi i u periodu 2013-2019. - Chávezova

${ }^{10}$ Iako je isprva bila protiv bolivarskog ustava, zanimljivo je da ga opozicija u poslednje vreme u potpunosti podržava, jer on odgovara njenoj poziciji (Salas, 2015: 169-170). 
smrt, problemi Madurovog autoriteta, ekonomska i izbeglička kriza u Venezueli, jačanje opozicije i omasovljenje protesta, kao i talas dolazaka desničara na vlast $u$ regionu biće činioci koji će, jedan za drugim, ubediti oportunistički Washington da su čavističkom režimu odbrojani dani i da je došlo vreme za seriju konkretnih poteza koji taj ishod treba da ubrzaju. Sve $u$ interesu da se naftom najbogatija latinoamerička država ponovo nađe u orbiti SAD - što i jeste primarni motiv Washingtona da se lati promene režima u Caracasu, a ne toliko ideologija čavizma sama po sebi, koja je ionako kompromitovana širom Latinske Amerike. ${ }^{11}$

Američki zaokret u pristupu venezuelanskom problemu išao je postepeno. Obama je prve sankcije protiv pojedinaca iz venezuelanskog establišmenta, u vidu uskraćivanja viza i zamrzavanja imovine, uveo na inicijativu "jastrebova" iz Senata (u prvom redu Marca Rubia) 2014, a zatim ih proširio 2015. (uz pomenuto opravdanje "neuobičajenom i izvanrednom pretnjom" po SAD) (Buxton, 2018: 19). Paralelno s tim činio je diplomatske napore u želji da izoluje Venezuelu - pre svega kroz Organizaciju američkih država (OAD), ali i pokušajem približavanja venezuelanskom mentoru Kubi, podržavajući u isto vreme opoziciju i njene pregovore sa režimom (Camilleri, 2018: 193-194). Trumpova politika prema Venezueli, uprkos nešto oštrijoj retorici, u početku je pre bila izraz kontinuiteta nego promene u odnosu na Obamu, što se menja tek u junu 2017, kad SAD ne uspevaju da nagovore OAD da usvoji antivenezuelansku rezoluciju. Nakon toga, administracija zauzima unilateralni pristup, proširujući sankcije na veći broj lica (uključujući samog Madura), da bi u avgustu ograničila venezuelanskoj vladi i PDVSA pristup američkom finansijskom tržištu (ali i dalje bez bojkota uvoza nafte) (ibid.: 190-192). Istog meseca, takođe nezadovoljne nejedinstvom unutar OAD, 12 latinoameričkih država, a na inicijativu novog predsednika Urugvaja, osniva antivenezuelansku Grupu iz Lime (Pantoulas, McCoy, 2019: 402; Buxton, 2019: 132).

Takođe u avgustu 2017, Trump je prvi put zapretio Venezueli oružanom intervencijom, na šta se nadovezao tadašnji državni sekretar Rex Tillerson izjavom da bi se demokratija u Venezueli mogla povratiti vojnim udarom (Camilleri, 2018: 194-195). Ovo nisu podržali ni američki vojni establišment (sekretar odbrane James Mattis rekao je da "venezuelanska kriza nije vojno pitanje") ni susedi Venezuele (Naím, Toro, 2018: 135-136). Trump je demonstrirao unilateralizam i aprila 2018, kada je propustio Samit dveju Amerika u Limi, ali će se njegova administracija pridružiti članicama Grupe iz Lime u izjavi da predstojećim predsedničkim izborima u Venezueli nedostaje legitimitet (Camilleri, 2018: 195; Campos, Prevost, 2019: 15). SAD će uoči izbora vršiti pritisak na Madurovog protivkandidata Henrija Falcóna da i on bojkotuje izbore, a pretiće i novim sankcijama ukoliko Maduro bude izabran

11 Nakon svrgavanja Eva Moralesa u Boliviji u novembru 2019, jedini radikalni socijalistički sledbenik Venezuele ostala je Nikaragva Daniela Ortege. 
(Kovalik, 2019: 70-71). Od 2018. na politiku SAD prema Venezueli sve više utiče novi savetnik za nacionalnu bezbednost John Bolton koji u jednom govoru na Floridi naziva Kubu, Nikaragvu i Venezuelu "trojkom tiranije" (Campos, Prevost, 2019: 14-15, 19). Nakon tog govora, Trumpova administracija još žešće kreće u obračun sa Venezuelom. Nakon što su Trump i potpredsednik Mike Pence garantovali Guaidóu da će ga podržati i priznati, a ovaj preuzeo vlast, Washington se odlučuje na radikalan i dotad nezamisliv potez - sankcije protiv PDVSA i zabranu uvoza nafte iz Venezuele (Kovalik, 2019: 159-160; Caldwell, 2019: 15; Campos, Prevost, 2019: 21). ${ }^{12}$ Jedina naftna veza SAD i Venezuele ostaće američka naftna kompanija Chevron, koja će nastaviti da posluje u toj zemlji (Caldwell, 2019: 18-20).

Da li prekid u trgovini naftom znači i napuštanje naftne logike u odnosima SAD i Venezuele, i to po prvi put u poslednjih 100 godina? Gledano iz ugla SAD, odgovor je negativan - ne samo da se ne radi o napuštanju, već se radi o vrhuncu naftne logike. Da nije nafte i onoga za šta se prihodi od nje mogu upotrebiti, ne bi ni došlo do eskalacije problema Venezuele u spoljnoj politici SAD. U vezi s tim, iza naftnih sankcija sigurno ne stoji namera Washingtona da pokida naftnu međuzavisnost sa Venezuelom, već naprotiv - da je samo nakratko suspenduje kako bi pao čavistički režim i kako bi ta međuzavisnost bila obnovljena u obliku kakav je postojao pre čavizma. Poenta svih ekonomskih sankcija SAD protiv Venezuele, uključujući i zabranu uvoza nafte, jeste u tome da se narod učini dovoljno očajnim da se digne protiv Madura i podrži Guaidóa za predsednika, što će državni sekretar Mike Pompeo (u martu 2019) i eksplicitno priznati: "Nema hrane. Nema lekova. Sada nema ni struje. Na redu je - nema Madura" (Kovalik, 2019: 94, 164). Međutim, skoro godinu i po dana od početka predsedničke krize i uvođenja naftnih sankcija, ovo se ne dešava. Trumpova administracija se očigledno preračunala u prognozi da će Maduro lako i brzo pasti, a svaki produžetak pat pozicije produžava i trajanje suspenzije naftne međuzavisnosti te možda i može da odvede ka objektivnom napuštanju naftne logike $u$ američko-venezuelanskim odnosima. Pošto ni narod ni vojska nisu svrgli Madura, preostala je poslednja opcija - vojna intervencija. Iako je u prvih nekoliko meseci 2019. delovalo da postoji ozbiljna opasnost da do te opcije dođe, ona je opet izostala. Očigledno je opstalo neslaganje unutar američkog establišmenta, posebno vojnog, o proceni rizika i isplativosti intervencije, kao i protivljenje latinoameričkih partnera - naročito nakon pozivanja Pompea i Boltona u prvim mesecima 2019. na Monroeovu doktrinu kao jedno od opravdanja za moguću intervenciju (Kovalik, 2019: 33; Buxton, 2019: 132-133; Camilleri, 2018: 196; Bahar, Piccone, Trinkunas, 2018: 8, 15-16).

12 Uz to, u januaru je za specijalnog predstavnika SAD za Venezuelu postavljen Elliott Abrams, ličnost kontroverzna po ulozi u aferi Iran-Kontra i zataškavanju brojnih zločina klijenata Washingtona po Srednjoj Americi (Kovalik, 2019: 99, 166, 171). 
Ovo je idealni trenutak da, pre nego što pređemo na zaključak, razmotrimo jedan novi aspekt - ulogu vanhemisfernih velikih sila Kine i Rusije u venezuelanskoj krizi i problemu Venezuele u spoljnoj politici SAD. Tri pitanja se nameću: koliko je bliskost čavističke Venezuele sa Kinom i Rusijom uticala na oštrinu problema koji ta zemlja predstavlja za Washington?; u kojoj meri naftna saradnja Venezuele sa Kinom i Rusijom omogućava Caracasu da smanji naftnu međuzavisnost sa SAD i time napusti naftnu logiku u odnosima s Washingtonom?; jesu li Kina ili Rusija odigrale ikakvu ulogu u odustajanju SAD od vojne intervencije u Venezueli u dosadašnjem toku krize? Na prvo pitanje nije tako teško odgovoriti - čavizam jeste trn u oku Washingtona zbog svojih veza sa Moskvom i Pekingom, naročito otkako su odnosi SAD i Rusije zaoštreni nakon Rusko-gruzijskog rata i ukrajinske krize, a sa Kinom se pojačava rivalstvo kako ova ekonomski raste. Što se aktuelne krize u Venezueli tiče, najveća bojazan SAD jeste da bi Kina i Rusija mogle da je eksploatišu kako bi ovladale venezuelanskim resursima, stekle privilegovane pozicije na venezuelanskom tržištu i čak ostvarile vojna uporišta u Venezueli, čime bi ovu definitivno udaljile od SAD - sve i da dođe do promene režima (Ellis, 2017b: 1-2). Početkom 2019. Bolton je nazvao jačanje ruskog vojnog prisustva u Venezueli "neposrednom pretnjom za međunarodni mir i bezbednost u regionu" (čitajte - pretnjom regionalnoj hegemoniji SAD) (Kovalik, 2019: 177).

Američka briga nije bez osnova. Oslanjanje Cháveza, a zatim i Madura na Kinu i Rusiju omogućilo je ovim zemljama velik udeo u eksploataciji venezuelanske nafte i u trgovini njome (Bahar, Piccone, Trinkunas, 2018: 8-9). Kina je najveći strani kreditor Venezuele, koja dugove plaća naftom i preferencijalnim pristupom kineskih firmi ugovorima za fabrike i infrastrukturu (Antonopoulos, Cottle, 2017: 60; Ellis, 2017b: 2-4, 8). ${ }^{13}$ Saradnja Venezuele i Rusije ojačala je nakon 2004, pošto su se oba režima politički konsolidovala, a rast cene nafte pomogao i jednom $i$ drugom (Sitenko, 2016: 43-44). Nakon Kine, Rusija je glavni finansijer čavističkog režima i sve više ulaže u venezuelanski naftni sektor, pre svega preko kompanije Rosnjeft (Ellis, 2017b: 8, 11-12). Nakon odbijanja SAD da prodaju naoružanje Venezueli, Rusija uskače i kroz svega par godina postaje najveći snabdevač Venezuele oružjem, kreditirajući Caracas da ga kupuje (Romero, Mijares, 2016: 184; Corrales, Romero, 2013: 32; Sitenko, 2016: 46; Ellis, 2017b: 9). Trgovina oružjem vremenom je prerasla i u širu vojnu saradnju, koja je obuhvatila zajedničke vojne vežbe Rusije i Venezuele. U periodu 2008-2019. ruski vojni brodovi i avioni u više navrata su posećivali Venezuelu, a uvećao se i broj ruskog vojnog osoblja koje u Venezueli boravi pod izgovorom redovnog tehničkog održavanja isporučene opreme, pa i pla-

${ }^{13}$ Kinesko-venezuelanska razmena skočila je sa 200 miliona dolara 1999. na 170 milijardi 2014. Izvoz nafte u Kinu skočio je sa 14 hiljada barela 2004. na 700 hiljada 2015. (Yin-Hang To, Acuña, 2019: 127-128). 
ćenika koji pomažu režimu; pominje se čak i mogućnost uspostavljanja ruske aviobaze na ostrvu Orchila (Mijares, 2017: 216; Corrales, Romero, 2013: 32-33; Ellis, 2017b: 11; 2019: 78). Ovakvo rusko vojno učešće u Venezueli je bez presedana u periodu nakon Hladnog rata i može se posmatrati kao neposredan odgovor Rusije na jačanje vojnog prisustva SAD u Istočnoj Evropi i delovima postsovjetskog prostora (Mijares, 2017: 221; Ciccarilo, 2016: 32; Ellis, 2017b: 10; Sitenko, 2016: 46-47). Venezuela se Rusiji pokazala kao idealno uporište za njene šire ambicije u Latinskoj Americi, čija integracija u jedinstven pol moći u nastajućem multipolarnom svetskom poretku predstavlja poželjan scenario za Moskvu (Ciccarilo, 2016: 29; Sitenko, 2016: 45). ${ }^{14}$

Da li pojačana naftna saradnja Venezuele sa Kinom i Rusijom znači potvrdan odgovor na naše drugo pitanje o mogućnosti da Caracas izađe iz "začaranog kruga" naftne međuzavisnosti s Washingtonom? Kako stoje stvari, a što dokazuje i aktuelan pad proizvodnje venezuelanske nafte, ne znači, jer geografski blisko i gladno američko tržište ništa ne može u potpunosti da zameni. Dokle god Venezuela ostane zavisna od nafte, ostaće u nekoj meri zavisna i od SAD. Odgovor na treće pitanje - jesu li se SAD uzdržale od vojne intervencije u Venezueli zbog učešća vanhemisfernih sila - nešto je teže dati, jer je legitimna hipoteza da se učestalo sletanje ruskih vojnih aviona u Venezuelu u jeku predsedničke krize nije slučajno poklopilo sa stišavanjem američkih pretnji. Iako je verovatno da je vojni establišment SAD uzimao u obzir i taj činilac pri proceni rizika od intervencije, očekivati da bi Rusija usred američkog "dvorišta" mogla da spase režim u Venezueli onako kako je spasla Bašara el-Asada u Siriji - ukoliko bi u nekom trenutku Washington zaista rešio da krene u invaziju, pa šta bude - bilo bi neozbiljno. Što ne znači da bi se Rusija prosto povukla i da nikakvog rizika od sukoba dveju velikih sila ne bi bilo - najmanje što bi moglo da se desi je da Moskva, nakon što bi režim pao, pomogne Kubi u njenoj podršci gerilskoj borbi delova vojske i kolektivosa lojalnih čavizmu (Ellis, 2019: 79). Uglavnom, američko-venezuelanski problem i dalje ostaje pretežno "unutrašnje" pitanje zapadne hemisfere.

\section{Zaključak}

Problem Venezuele u spoljnoj politici Sjedinjenih Država pojavio se sa usponom Huga Cháveza na vlast 1999. godine, ali ima korene i u ranijoj istoriji američko-venezuelanskih odnosa. Njih je u periodu od oko osam decenija karakterisalo

14 Putin je u jednom intervjuu 2014. izjavio: "Zainteresovani smo za jaku, ekonomski stabilnu i politički nezavisnu, ujedinjenu Latinsku Ameriku, koja bi postala značajan deo multicentričnog svetskog poretka u nastajanju" (Ciccarilo, 2016: 39). Inače, na međunarodnom planu se čavistička Venezuela redovno svrstava uz Rusiju. Između ostalog, jedna je od retkih država sveta koja je priznala nezavisnost Abhazije i Južne Osetije (Corrales, Romero, 2013: 33). 
savezništvo zasnovano na naftnoj međuzavisnosti. Washington je tolerisao aktivnu regionalnu spoljnu politiku Venezuele dokle god mu ona nije bila suštinski suprotstavljena, istovremeno zanemarujući "tempiranu bombu" ranjive ekonomije i društvenih nejednakosti unutar Venezuele, nastalu kao posledicu lošeg upravljanja Caracasa sopstvenim naftnim bogatstvom. Nakon što je "bomba" eksplodirala i ustoličila čavistički režim, naftna međuzavisnost ostala je jedina brana eskalaciji američko-venezuelanskog sukoba, jer je i za oportunistički Washington i za Cháveza bilo preskupo da pređu "crvenu liniju" u smislu radikalnih poteza koji bi ovoj međuzavisnosti naškodili. Međutim, nakon što je Chávez umro, Venezuela se suočila sa najvećom ekonomskom krizom u istoriji i posledičnom političkom destabilizacijom, a regionalna ideološka slika se promenila u pravcu jačanja desnice, SAD je "nanjušio" priliku za konačan obračun sa čavizmom svim raspoloživim sredstvima - uključujući i privremeno kidanje naftnih veza. Kako je čavizam opstao uprkos krizi, a Washington ipak nije pribegao poslednjem sredstvu koje mu stoji na raspolaganju - vojnoj intervenciji - pat pozicija je dočekala globalnu pandemiju korona virusa. Ako pretpostavimo da će se ova pandemija kad-tad suzbiti, a problem Venezuele i nakon nje opstati u konturama kakve smo ovde izložili, postavlja se pitanje: kakve su njegove dalje perspektive i šta bi trebalo da se desi da se on prevaziđe?

Opcija američke vojne intervencije, uprkos svim rizicima koje bi nosila sa sobom, uvek ostaje na stolu ako Washington proceni da drugog načina da režim padne nema. Mnogo je teže očekivati da SAD dozvole da Maduro unedogled ostane na vlasti i da eventualno s njim uspostave koegzistenciju kakvu su imale sa Chávezom, jer su "tačku bez povratka" već prešle kada su priznale Guaidóa za predsednika, a kidanjem naftnih veza su izmakle poslednju osnovu koja je omogućavala prethodnu koegzistenciju sa Chávezom. No, čak i da dođe do promene režima u Caracasu po želji Washingtona, tu problemu ne bi bio kraj, jer nema nikakvih garancija da bi novi režim bolje upravljao naftnim bogatstvom Venezuele i tako sprečio da se pre ili kasnije ponovi društveno-politička situacija koja je iznedrila čavizam. Već i Maduro pokušava nešto da promeni u ekonomskoj politici, između ostalog i dolarizacijom, ali vidljivo zanemaruje stvarne uzroke krize, prikazujući ih isključivo kao proizvod ekonomskog rata SAD protiv Venezuele, dok je čavistička radikalna levičarska ideologija direktno suprotstavljena ideji o štednji naftnog bogatstva (Gill, 2018b: 311-312; Gallegos, 2016: 190-192). Ali, ni odricanje od ove ideologije neće poništiti latinoamerički mentalitet i očekivanja koja različiti društveni slojevi u Venezueli imaju od svakog režima koji dođe u smislu raspodele naftnog bogatstva, tako da Venezuelancima praktično ostaje da se mole da će ih novi rast cene nafte spasti od sopstvenih grešaka (Gallegos, 2016: 201). ${ }^{15}$

15 A cena nafte je na početku pandemije, usled drastičnog pada potražnje, nikad niža. 
To znači da je "lopta" na američkoj strani terena. Ako želi istinski da reši venezuelanski problem, Washington bi morao da povede računa o pomenutim činjenicama u vezi sa karakterom venezuelanskog društva i ekonomije, a ne da se zadovolji samo lojalnošću režima u Caracasu. Trumpova administracija nije pokazala nameru da ozbiljnije pomogne rekonstrukciju venezuelanske ekonomije nakon što bi došlo do smene režima - naprotiv, nespremnost na taj potez je jedan od razloga zašto se odustalo od vojne intervencije, jer bi onda odgovornost Washingtona za obnovu Venezuele bila mnogo veća (Bahar, Piccone, Trinkunas, 2018: 8). Uz to, kod Trumpa je naglašen i činilac ideološke netrpeljivosti prema svim socijalističkim režimima u okruženju, a postoje mišljenja da je to zato što je ideja socijalizma sve popularnija i u samim SAD - što pokazuje primer popularnosti Berniea Sandersa ${ }^{16}$ - te bi je trebalo "ugušiti" u Latinskoj Americi kako bi prestala da pruža primer domaćoj javnosti (Kovalik, 2019: 172). Možda ovo jeste putokaz ka rešenju - washingtonski establišment bi pre ili kasnije morao da shvati (možda će ga u to ubediti tekuća pandemija) da bi neka vrsta socijalizma - koji ne mora da bude radikalan, niti autoritaran, poput čavističkog - bila imperativ za pojedina latinoamerička društva, uključujući i venezuelansko, kako bi ona rešila svoje probleme. Naravno, uz bolje upravljanje ekonomijom i prirodnim resursima, a Washington bi u tome mogao da im pomogne - nakon što najpre pomogne sebi i razume da je preterano rigidno insistiranje na neoliberalnom kapitalizmu (suprotno inače oportunističkom ponašanju) dugoročno kontraproduktivno za opstanak regionalne hegemonije, a svakako za nacionalni interes Sjedinjenih Država.

\section{LITERATURA}

Antonopoulos, Paul i Cottle, Drew. 2017. Venezuela's 2017 Crisis: A Failed Bolivarian Experiment or a Legitimate Claim of US Imperialism?. Critique, (46), 1: 49-64.

Bahar, Dany, Piccone, Ted, Trinkunas, Harold. 2018. Venezuela: A Path Out of Misery. Brookings Policy Brief.

Briceño-Ruiz, José. 2019. The Crisis in Venezuela: A New Chapter, or the Final Chapter. Latin American Policy, (10), 1: 180-189.

Buxton, Julia. 2018. Defusing Venezuela. Seton Hall Journal of Diplomacy and International Relations: 7-24.

Buxton, Julia. 2019. The Missteps of Venezuela's Opposition - Again. NACLA Report on the Americas, (51), 2: 130-133.

${ }^{16}$ Doduše, Bernie Senders je 2020, uprkos porastu popularnosti, po drugi put doživeo poraz u borbi za mesto kandidata Demokratske partije na predsedničkim izborima. 
Caldwell, Sarah. 2019. Venezuela's Collapsed Economy and the Resulting Effect on International Business with the United States. PhD dissertation. Liberty University. Lynchburg.

Camilleri, Michael J. 2018. Evolution or Revolution? U.S. Policy on Venezuela from Obama to Trump. Venezuela: la multidimensionalidad de una crisis hemisférica: 189-205.

Campos, Carlos Oliva i Prevost, Gary. 2019. The Trump Administration in Latin America: Continuity and Change. International Journal of Cuban Studies, (11), 1: 13-23.

Ciccarilo, Simon Gaetano. 2016. The Russia-Latin America Nexus: Realism in the 21st Century. Review of International Studies: 25-45.

Corrales, Javier i Romero, Carlos. 2013. U.S.-Venezuela Relations Since the 1992: Coping with Midlevel Security Threats. Routledge. New York.

Ellis, Evan. 2017a. The Collapse of Venezuela and Its Impact on the Region. Military Review, (97), 4: 22-33.

Ellis, R. Evan. 2017b. The Influence of Extra-Hemispheric Actors on the Crisis in Venezuela. Testimony to the Subcommittee on Western Hemisphere Affairs. Foreign Affairs Committee, U.S. House of Representatives, September 13.

Ellis, R. Evan. 2019. Russian Activities in Latin America, u: Russian Strategic Intentions. Dudley Knox Library. Monterey: 76-81.

Gallegos, Raúl. 2016. Crude Nation: How Oil Riches Ruined Venezuela (electronic issue). Potomac Books. Lincoln.

Gill, Timothy M. 2018a. From Promoting Political Polyarchy to Defeating Participatory Democracy: U.S. Foreign Policy towards the Far Left in Latin America. Journal of World System Research, (24), 1: 72-95.

Gill, Timothy M. 2018b. The Possibilities and Pitfalls of Left-Wing Populism in Socialist Venezuela. Journal of World System Research, (24), 2: 304-313.

Kovalik, Dan. 2019. The Plot to Overthrow Venezuela: How the US Is Orchestrating a Coup for Oil (electronic issue). Hot Books. New York.

Mearsheimer, John J. 2001. The Tragedy of Great Power Politics. Norton. New York.

Mearsheimer, John J. 2011. Imperial by Design. The National Interest, 111: 16-34.

Mijares, Víctor M. 2015. Venezuela's Post-Chavez Foreign Policy: Is There a Maduro Doctrine?. America's Quarterly, (9), 1: 74-81.

Mijares, Víctor M. 2017. Soft Balancing the Titans: Venezuelan Foreign-Policy Strategy Toward the United States, China, and Russia. Latin American Policy, (8), 2: 201-231.

Morgenthau, Hans J. 1952. What Is the National Interest of the United States?. Annals of the American Academy of Political and Social Science, (281), 1: 1-7.

Naím, Moisés i Toro, Francisco. 2018. Venezuela's Suicide. Foreign Affairs, (97), 6: 126-138. 
Pantoulas, Dimitris i McCoy, Jennifer. 2019. Venezuela: An Unstable Equilibrium. Revista de Ciencia Política, (39), 2: 391-408.

Pavlova, Elena. 2018. A Russian Challenge to Multipolarity? The Prospects for Political Cooperation between Russia and Latin America. Problems of Post-Communism, (65), 6: 394-408.

Posen, Barry R. 2014. Restraint: A New Foundation for U.S. Grand Strategy. Cornell University Press. Ithaca i London.

Romero, Carlos A. i Mijares, Víctor M. 2016. From Chavez to Maduro: Continuity and Change in Venezuelan Foreign Policy. Contexto Internacional, (38), 1: 165-201.

Salas, Miguel Tinker. 2015. Venezuela: What Everyone Needs to Know. Oxford University Press. New York.

Sitenko, Alexandra. 2016. Latin American Vector in Russia's Foreign Policy: Identities and Interests in the Russian-Venezuelan Partnership. Politics in Central Europe, (12), 1: 37-57.

Yin-Hang To, Miriam Emma i Acuña, Rodrigo. 2019. China and Venezuela: South-South Cooperation or Rearticulated Dependency?. Latin American Perspectives, (46), 2: 126-140.

Vladimir Trapara

\title{
THE VENEZUELA PROBLEM IN UNITED STATES FOREIGN POLICY
}

\begin{abstract}
Summary
The author deals with the United States and Venezuela relations up to the current presidential crisis, in order to answer how and why Venezuela became a problem for U.S. foreign policy which requires increased attention and radical measures. The analysis of these relations during the 20th century shows that they were based on oil interdependence of the two states. When a decades-long mismanagement of oil riches in Venezuela at the end of the century caused a social and economic crisis that brought to power Hugo Chávez, who was ready to use oil revenues against U.S. regional hegemonic interests, it marked Venezuela as a problem. American establishment treated the problem with opportunism - oil interdependence prevented the conflict from escalating until the current economic and political crisis in Venezuela after the death of Chávez gave Washington an opportunity for the final clash with the regime at the price of a temporary break in the oil trade. A year and a half after the presidential crisis in Venezuela erupted, it has not been resolved yet, for the chavista regime remained in place, while the U.S.
\end{abstract}


gave up on military intervention. The author points to the perspectives of the problem and the possibilities of its overcoming once the current coronavirus pandemic gets contained.

Keywords: Venezuela, United States, Foreign Policy, Oil, Chavism

Vladimir Trapara je znanstveni suradnik na Institutu za međunarodnu politiku i privredu u Beogradu.

Kontakt: Vladimir Trapara, Institut za međunarodnu politiku i privredu, Makedonska 25, 11000 Beograd, Srbija. E-mail: vtrapara@diplomacy.bg.ac.rs 